\title{
A Comparative Study of Arbuscular Mycorrhizal Fungi, Phosphate Solubilizing Bacteria and Phosphate Fertilizer Effects on Growth, Yield and Mineral Contents of Common Bean (Phaseolus Vulgaris L.)
}

\author{
Elkhatib, H.A., S.M. Gabr ${ }^{1}$, F.I.Radwan ${ }^{2}$ and R.F. Abo El-Ali ${ }^{3}$
}

\begin{abstract}
Two field experiments were conducted at ELMahmodia region, (Behera Governorate) Egypt, to assess the influence of applying four different fertilization levels of mineral phosphourous $\left(0,30,60\right.$ and $90 \mathrm{Kg} \mathrm{P}$ fed $^{-1}$. ) in addition to seed inoculation with phosphorous solubilizing bacteria (Bacillus megaterium; cited as a commercial product phosphorein from Agriculture Research Center), and arbuscular mycorrhizal fungi (Glomus macrocarpium) on the growth and flowering traits, green pod yield and its components and leaves contents of $N, P$ and $K$ of bronco cultivar of common bean (Phaseolus vulgaris L.) cv. "Bronco. The results showed that mycorrhiza and phosphorein had similar effects on vegetative growth characters and flowering traits; meanwhile, mycorrhiza gave a higher yield fed $^{-1}$ than the inoculation with phosphorein in both seasons. On the other hand fertilizing common bean plants with inorganic phosphorus at the rates of 30, 60 and $90 \mathrm{~kg}_{2} \mathrm{O}_{5}$ fed $^{-1}$, significantly, increased most of vegetative growth characters, number of flowers plant $^{-1}$, fruit set percentage, green pods yield and $\mathbf{N}$ and $P$ contents of leaves; compared to the control treatment in both seasons. The highest two phosphorus levels (60 and 90 $\mathrm{kg} \mathrm{P}_{2} \mathrm{O}_{5}$ fed $^{-1}$ ) were remarkable and associated with the highest mean values in this concern, whereas, the differences between them were insignificant. Most of the interaction effects of biofertilizer types and mineral phosphorus levels on the various studied characters were found significant in both seasons. The combined treatments of mycorrhiza and $60 \mathrm{~kg} \mathrm{P}_{2} \mathrm{O}_{5}$ fed $^{-1}$, was considered the best treatment combinations, and gave the highest mean value of green pods yield in both seasons.
\end{abstract}

\section{INTRODUCTION}

The striking increase in the uses of mineral fertilizers fertilizers by the intensive agricultural practices had led to clear degradations of soil, air and water quality. Therefore; the application of biofertilization by using micro-organisms to improve soil fertility through their activities providing most of the essential nutrients required to plant growth and crop productivity. The microbial biomass is important in soil through various activities and through the potential to

\footnotetext{
${ }^{1}$ Horticulture Dept.Faculty of Agriculture,Damanhour Branch Alex. Univ.

${ }^{2}$ Agronomy Dept, Faculty of Agriculture, Saba Basha Alex. Univ.

${ }^{3}$ Ministry of Agriculture Alex.

Received September 3, 2008, Accepted September30, 2008
}

act as nutrients sink/source (Schmirer and Rosswall, 1987).

Phosphorus is the second to nitrogen as a mineral nutrient required by both plants and micro-organisms. It is also one of the major nutrients limiting plant growth. Although bound $\mathrm{P}$ is quite abundant in many soils, it is largely unavailable for plant uptake. Crop yield on $40 \%$ of the world's arable land is limited by $\mathrm{P}$ availability. As currently practiced, agriculture will require $55-60 \times 10^{6}$ $\mathrm{Mt}$ of $\mathrm{P}$ fertilizer applied to agricultural soils to meet food production needs in 2040 (FAO. 2003). However, $P$ is not a renewable resource and its future use in agriculture will be impacted by declining availability and increased cost. Moreover, the striking increase in the use of fertilizers by intensive agriculture practices has led to degradation of air and water quality. Therefore, sustainable management of $\mathrm{P}$ in agriculture requires strategies to enhance its acquisition or uptake by plants. In this context, the most realistic solution according to Marschner (1995) is the use of Arbuscular mycorrhizal (AM) fungi and phosphate solubilizing bacteria (PSB) that have the ability to acquire $\mathrm{P}$ and give high yield under $\mathrm{P}$ limited supply.

Phosphate solubilizing bacteria (Phosphorein) and fungus (Arbuscular mycorrhizae) have the capability to mobilize phosphate, micronutrients and phytohormones such as gibberellins, auxins and cytokinins, in addition of promoting root development and thereby enhance nutrient uptake (Marschner, 1995). Phosphate solubilizing bacteria plays a fundamental role in correcting the solubility problem in soil by transforming the insoluble phosphate to soluble forms by secreting organic acids such as formic, acetic, lactic, propionic, fumaric and succinic acids. Those acids lower the $\mathrm{pH}$ and bring the dissolution of bond forms of phosphate and render them available for growing plants (Ashour 1998). On the other hand Arbuscular mycorrhizal fungi develop a hyphal network that serves as a fundamental link between the soil, the nutrient reservoir and the plant. This hyphal network is more efficient for ion uptake than root hairs (Dorneless et al. 2001). 
Arbuscular mycorrhizae can also provide many nonnutritional benefits to crops, including: alleviation of water (Allen and Boosalis 1983) and salt stress (Ruizlozano et al. 1996), protection against some soil-borne pathogens (Roncadori and Hussey 1977) and improvements to soil structure (Hamel et al. 1997).

Common bean is the world's most important food legume (Pachico, 1993). Beans offer a low cost alternative to beef and milk because bean seeds provide substantial quantities of minerals and vitamins, complex carbohydrates, dietary fiber, flavones, antioxidants and anticarcinogenic compounds (Bennink, 2001). The total area planted in Egypt with Common bean cultivars was 54179 feddans with a total annual production of 128540 ton of green beans and 29331 ton of dry seeds (Agricultural statistics, 2004). Beans require adequate P from the very early stages of growth for optimum crop production. Phosphorus supply to the crop is affected by soil $\mathrm{P}$ and by soil and environmental conditions. $\mathrm{P}$ fertilization may improve $\mathrm{P}$ nutrition and crop yield potential. Alternately, encouragement of Phosphate solubilizing microorganisms may enhance $\mathrm{P}$ uptake by crops early in the growing season, improving crop yield potential and replacing fertilizer applications.

Therefore, the objective of this study was: (1) to investigate inoculation effects of arbuscular mycorrhizae fungus and phosphate solubilizing bacteria (PSP), under different levels of mineral phosphate fertilizer on growth, green yield and chemical composition of common bean plants.

\section{MATERIALS AND METHODS}

This study was conducted in two successive fall growing seasons of 2004 and 2005 at the Experimental Farm at El-Bostan, Faculty of agriculture, Damanhour Branch, Alexandria University. The physical and chemical characteristics of the soil (Table 1) were determined according to the methods reported by Page et al. (1982).

\section{Experimental Design:}

The experiments were carried out using a randomized complete blocks design with four replications containing eight studied treatments comprised of the combinations of four phosphorus rates $\left(0,30,60\right.$ and $90 \mathrm{Kg} \mathrm{P}_{2} \mathrm{O}_{5}$ fed $\left.^{-1}\right)$ and two biofertilizers types (phosphorein and mycorrhiza). Mineral phosphorus fertilizer was applied during soil preparation, in the form of calcium superphosphate $\left(15.5 \% \mathrm{P}_{2} \mathrm{O}_{5}\right)$. All experimental units received $60 \mathrm{~kg} \mathrm{~N}$ fed $^{-1}$ in the form of ammonium sulphate $(20.5 \% \mathrm{~N})$ and $48 \mathrm{~kg} \mathrm{~K}_{2} \mathrm{O}$ fed $^{-1}$ in the form of potassium sulphate $(48 \%$ $\mathrm{K}_{2} \mathrm{O}$ ) in three equal portions at 2, 4 and 6 weeks from sowing. Each experimental plot area was $15 \mathrm{~m}^{2}$ and contained 5 ridges, $5 \mathrm{~m}$ long and $0.6 \mathrm{~m}$ width and each two adjacent experimental units were separated by a guard row. Bean seeds were sown on one side of the row, on September 6 and 9 of 2004 and 2005 seasons respectively, at an intra-row spacing of $10 \mathrm{~cm}$. In each plot, the plants of the first three rows were allocated to measure the vegetative growth characters, chemical constituents and green pods yield and its components.

\section{Seed inoculation:}

Seeds of the common bean cultivar Bronco were inoculated by Vesicular Arbuscular Mycorrhiza fungi (VAM) inoculum in the form of Glomus macrocarpium supplied by the Biofertilizer Unit, Faculty of Agriculture of Saba Basha, Alexandria University. Ten grams of mycorrhizal inoculum consisted of infected root fragmens, spores and mycelium contained 25 spores $\mathrm{g}^{-1}$ was added into each planting hole at sowing time.

Inoculation of Phosphate solubilising bacteria (PSB) was conducted using the product of Agricultural Research Center and called phosphorein that contains active bacteria (Bacillus megaterium) which converse the insoluble tricalcium phosphate to the soluble mono calcium phosphate. The inoculation was performed by coating the seeds at the rate of $40 \mathrm{gms} / \mathrm{kg}$ of seeds using a staking substance (Arabic gum 5\%) just before sowing.

Table1. The main physical and chemical properties of soils of the experimental sites of 2004 and 2005 seasons

\begin{tabular}{lcc}
\hline \multicolumn{1}{c}{ Parameters } & \multicolumn{2}{c}{ Seasons } \\
\cline { 2 - 3 } & $\mathbf{2 0 0 4}$ & $\mathbf{2 0 0 5}$ \\
\hline Physical properties & & \\
Clay\% & 8.00 & 8.00 \\
Silt\% & 4.00 & 4.00 \\
Sand\% & 88.00 & 88.00 \\
Soil texture & sand & sand \\
Chemical properties & & \\
PH & 8.00 & 8.13 \\
EC(dSm $\left.{ }^{-1}\right)$ & 1.20 & 1.17 \\
CaCO $_{3}$ & 2.10 & 2.04 \\
Macro-elements (ppm) & & \\
N & 20.00 & 23.00 \\
P & 18.00 & 23.00 \\
K & 184.00 & 176.00 \\
\hline
\end{tabular}

\section{Recorded Data}

The data of the various studied characters were measured as follows:

\section{Vegetative growth characters:}

The data of vegetative growth characters were recorded using five randomly chosen plants from each plot, at 60 days from seed sowing. The following measurements were recorded: plant height, number of leaves and branches plant ${ }^{-1}$, plant fresh weight ,root 
length and leaf area plant ${ }^{-1}$ that was estimated using the weight method as reported by Fayed (1997).

Leaves fresh weight $\times 20^{*} \times$ area of disk

Leaf area per plant $=$

Fresh weight of 20 disk $\times 3^{* *}$

where $20^{*}=$ number of random disks taken from the leaves

$3^{* *}=$ number of plants per sample

\section{Green pods yield and its components:}

At harvesting time plants of the second and third rows were allocated to measure the following data: number, length and weight of green pods plant $^{-1}$ and green pods yield fed. ${ }^{-1}$

\section{Chemical Contents of Leaves:}

Wet digestion procedure was performed on leaves according to Chapman and Pratt (1978) and the following determinations were carried out in the digested solution: total phosphorus and potassium (determined as reported by Jackson, 1967),total nitrogen (determined using micro- kjeldahl method according to Ling ,1963).

\section{Statistical Analysis:}

All obtained data were statistically analyzed using SAS software program (1996). Comparisons among the means of different treatments were conducted using the revised least significant difference test at $\mathrm{P}=0.05$ level as illustrated by Al-Rawy and Khalf-Allah (1980).

\section{RESULTS AND DISCUSSIONS}

The effects of the two studied factors and their interaction on the various characters of common bean plants during 2004 and 2005 seasons could be classified under five main headings as follow: vegetative growth characters, flowering traits, green pods yield and its components and chemical contents of leaves.

\section{Vegetative Growth Characters:}

\section{Effects of the biofertilizer types:}

Data of the main effects of the two biofertilizer types and mineral $\mathrm{P}$ fertilizer rates on vegetative growth characters of common bean plants, Tables (2 and 3) indicated that inoculating common bean seeds either with Phosphorein or Mycorrhiza did not reflect any significant difference between their effects on all studied vegetative growth characters which included plant height, root length, number of branches plant ${ }^{-1}$, root, stem and plant fresh weight and leaf area in both seasons - Similar results were reported by several researchers such as Ashour (1998) on seed potato tubers; ELshamma (2000) on dry bean; EL- shimi (2003) on sweet potato; also Hassan et al (2005) found that the addition of bio - phosphorus fertilizers (phosphorein or
Mycorrhiza) resulted in significant increases in plant length, number of branches plant ${ }^{-1}$ and leaf area plant ${ }^{-1}$ of sweet potato plants .

\section{Effects of mineral phosphorus fertilizer}

Tables (2and 3) clearly, showed that the application of 30, 60 and $90 \mathrm{Kg} \mathrm{P} \mathrm{P}_{5} \mathrm{O}_{5} \mathrm{fe}^{-1}$ to the growing plants , increased significantly plant height, root length, number of branches plant ${ }^{-1}$, plant fresh weight, root fresh weight, stem fresh weight, leaf area relative to the control treatment, in both seasons. The detected differences showed that the percentages of the increments of plant fresh weight were $10.22 \%, 28.78 \%$ and $22.47 \%$ in fall season of 2004 and $7.94 \%, 20.41 \%$ and $14.14 \%$ in fall season of 2005 as a result of using 30,60 and $90 \mathrm{~kg}_{2} \mathrm{O}_{5}$ fed $^{-1}$ respectively. Also the comparisons among the mean values of each studied vegetative growth character indicated that, whether $\mathrm{P}$ application rate was 60 or $90 \mathrm{P}_{2} \mathrm{O}_{5} \mathrm{fed}^{-1}$, the studied vegetative growth characters reflected the best positive effects. Moreover, the differences between these two P levels were insignificant on all previously mentioned characters. The promoting effect on growth parameters could be attributed to the fundamental role of phosphorous as a structural part of many compounds; nucleic acids, phospholipids, co enzymes NAD and NADP, ATP and other high energy compounds (Srag, 2004). It is also a constituent of the cell nucleus and is essential for cell division and the development of meristematic tissues (Russell, 1973). Moreover, phosphorus is ubiquitous and essential element in the energy transfer processes. Similar positive results were reported by several researchers working on different vegetables such as El - Kalla et al. ( 1997 ) on faba bean and onion, El - Shamma ( 2000 ) on dry bean. Also Feleafel and El - Araby ( 2001 ) found that the application of $\left(60 \mathrm{~kg} \mathrm{P}_{2} \mathrm{O}_{5} \mathrm{fed}^{-1}\right)$ to the common bean plants led to significant increments in average plant height, number of leaves and branches plant ${ }^{-1}$, fresh and dry masse plant ${ }^{-1}$ and leaves area plant $^{-1}$ of common bean plants. Srag (2004) reported that vegetative growth characters of pea plants, were significantly, increased by increasing phosphorus fertilizer.

\section{Interaction effects:}

The interaction effects between biofertilizer types and phosphorus fertilizer rates on vegetative growth character, in the two seasons of 2004 and 2005 are illustrated in Tables (4 and 5). The results showed that there were significant differences between the effects of the two biofertilizer types at the different phosphorous levels on plant height, root length, number of branches plant $^{-1}$, plant fresh weight, root fresh weight, stem fresh weight, leaves dry weight, stem dry weight, plant dry weight and leaf area. The favoring effects of the 
Table 3. The main effects of biofertilizer types and phosphorus fertilizer rates on the vegetative growth characters of common bean plants during the seasons of 2004 and 2005

\begin{tabular}{|c|c|c|c|c|}
\hline \multirow{2}{*}{ Treatments } & \multicolumn{2}{|c|}{ Leaf area plant ${ }^{-1}\left(\mathrm{~cm}^{2}\right)$} & \multicolumn{2}{|c|}{ Number of branches plant ${ }^{-1}$} \\
\hline & 2004 & 2005 & 2004 & 2005 \\
\hline \multicolumn{5}{|l|}{ Biofertilizer types } \\
\hline Phosphorein & $782.05 \mathrm{a}^{*}$ & 858.64 a & $4.01 \mathrm{a}$ & $4.43 \mathrm{a}$ \\
\hline Mycorrhiza & $841.62 \mathrm{a}$ & $903.00 \mathrm{a}$ & $4.30 \mathrm{a}$ & $4.66 \mathrm{a}$ \\
\hline \multicolumn{5}{|l|}{$P$ rate $\left(\mathrm{kg} \mathrm{P}_{2} \mathrm{O}_{5} \mathrm{fed}^{-1}\right)$} \\
\hline 0 & $713.02 \mathrm{~b}$ & $807.77 \mathrm{c}$ & $3.65 \mathrm{~b}$ & $4.17 \mathrm{~b}$ \\
\hline 30 & 807.73 a & $872.54 \mathrm{bc}$ & $4.27 \mathrm{a}$ & $4.50 \mathrm{ab}$ \\
\hline 60 & $873.32 \mathrm{a}$ & $942.51 \mathrm{ab}$ & $4.37 \mathrm{a}$ & $4.77 \mathrm{a}$ \\
\hline 90 & $853.27 \mathrm{a}$ & $900.46 \mathrm{abc}$ & $4.32 \mathrm{a}$ & $4.72 \mathrm{a}$ \\
\hline
\end{tabular}

${ }^{*}$ Values having a common alphabetical letter (s), do not significantly differ, using the revised L.S.D. test at $\mathrm{P}=0.05$.

Table 4. The interaction effects of biofertilizer types and phosphours fertilizer rates on the vegetative growth characters of common bean plants during the seasons of 2004 and 2005

\begin{tabular}{|c|c|c|c|c|}
\hline \multirow[t]{3}{*}{$P$ rate $\left(\mathrm{kg} \mathrm{P}_{2} \mathrm{O}_{5}\right.$ fed $\left.^{-1}\right)$} & \multicolumn{2}{|c|}{2004} & \multicolumn{2}{|c|}{2005} \\
\hline & \multicolumn{4}{|c|}{ Plant height (cm) } \\
\hline & Phosphorein & Mycorrhiza & Phosphorein & Mycorrhiza \\
\hline 0 & $34.16 b^{*}$ & $33.28 \mathrm{~b}$ & $31.09 \mathrm{~b}$ & $37.30 \mathrm{ab}$ \\
\hline 30 & $35.89 \mathrm{ab}$ & $40.69 \mathrm{a}$ & $37.77 \mathrm{ab}$ & $41.46 \mathrm{a}$ \\
\hline 60 & $38.53 \mathrm{ab}$ & $41.57 \mathrm{a}$ & $41.58 \mathrm{a}$ & $42.59 \mathrm{a}$ \\
\hline 90 & $37.79 \mathrm{ab}$ & $42.67 \mathrm{a}$ & $39.98 \mathrm{ab}$ & $42.77 \mathrm{a}$ \\
\hline
\end{tabular}

\begin{tabular}{|c|c|c|c|c|}
\hline & \multicolumn{4}{|c|}{ Root length (cm) } \\
\hline & Phosphorein & Mycorrhiza & Phosphorein & Mycorrhiza \\
\hline 0 & $9.90 \mathrm{~b}$ & $11.03 \mathrm{ab}$ & $11.43 \mathrm{~b}$ & $11.62 \mathrm{ab}$ \\
\hline 30 & $10.37 \mathrm{ab}$ & $11.54 \mathrm{ab}$ & $11.75 \mathrm{ab}$ & $11.95 \mathrm{ab}$ \\
\hline 60 & $10.40 \mathrm{ab}$ & $12.13 \mathrm{a}$ & $12.69 \mathrm{ab}$ & $13.06 \mathrm{a}$ \\
\hline \multirow[t]{3}{*}{90} & $10.68 \mathrm{ab}$ & $11.85 \mathrm{ab}$ & $12.28 \mathrm{ab}$ & $12.51 \mathrm{ab}$ \\
\hline & \multicolumn{4}{|c|}{ Root fresh weight $^{-1}(\mathrm{~g})$} \\
\hline & Phosphorein & Mycorrhiza & Phosphorein & Mycorrhiza \\
\hline 0 & $1.66 \mathrm{c}$ & $2.02 \mathrm{bc}$ & $1.90 \mathrm{~d}$ & $2.24 \mathrm{~cd}$ \\
\hline 30 & $2.28 \mathrm{abc}$ & $2.48 \mathrm{ab}$ & $2.39 \mathrm{~cd}$ & $2.54 \mathrm{bc}$ \\
\hline 60 & $2.66 \mathrm{a}$ & $2.88 \mathrm{a}$ & $2.95 \mathrm{ab}$ & $3.10 \mathrm{a}$ \\
\hline \multirow[t]{3}{*}{90} & $2.76 \mathrm{a}$ & $2.85 \mathrm{a}$ & $2.89 \mathrm{ab}$ & $3.02 \mathrm{ab}$ \\
\hline & \multicolumn{4}{|c|}{ plant fresh weight (g) } \\
\hline & Phosphorein & Mycorrhiza & Phosphorein & Mycorrhiza \\
\hline 0 & $52.89 \mathrm{~b}$ & $56.14 \mathrm{ab}$ & $60.81 \mathrm{~b}$ & $62.91 \mathrm{ab}$ \\
\hline 30 & $56.57 \mathrm{ab}$ & $62.92 \mathrm{ab}$ & $63.97 \mathrm{ab}$ & $65.11 \mathrm{ab}$ \\
\hline 60 & $62.98 \mathrm{ab}$ & $67.71 \mathrm{a}$ & $67.93 \mathrm{ab}$ & $72.50 \mathrm{a}$ \\
\hline 90 & $63.53 \mathrm{ab}$ & $64.94 \mathrm{ab}$ & $66.39 \mathrm{ab}$ & $64.68 \mathrm{ab}$ \\
\hline
\end{tabular}

* Values having a common alphabetical letter (s), do not significantly differ, using the revised L.S.D. test at $\mathrm{P}=0.05$. 
Table 5. The interaction effects of biofertilizer types and phosphours fertilizer rates on the vegetative growth characters of common bean plants during the seasons of 2004 and 2005

\begin{tabular}{|c|c|c|c|c|}
\hline \multirow[t]{3}{*}{$P$ rate $\left(\operatorname{kg~P}_{2} \mathrm{O}_{5}\right.$ fed $\left.^{-1}\right)$} & \multicolumn{2}{|c|}{2004} & \multicolumn{2}{|c|}{2005} \\
\hline & \multicolumn{4}{|c|}{ Leaves fresh weight (g) } \\
\hline & Phosphorein & Mycorrhiza & Phosphorein & Mycorrhiza \\
\hline 0 & $29.19 \mathrm{a}^{*}$ & 30.56 a & $33.57 \mathrm{a}$ & $34.38 \mathrm{a}$ \\
\hline 30 & $31.28 \mathrm{a}$ & $33.20 \mathrm{a}$ & $34.06 \mathrm{a}$ & $34.36 \mathrm{a}$ \\
\hline 60 & $31.80 \mathrm{a}$ & $34.64 \mathrm{a}$ & $35.17 \mathrm{a}$ & $37.03 \mathrm{a}$ \\
\hline 90 & $33.34 \mathrm{a}$ & $33.69 \mathrm{a}$ & $34.84 \mathrm{a}$ & 3588 a \\
\hline
\end{tabular}

\begin{tabular}{|c|c|c|c|c|}
\hline & \multicolumn{4}{|c|}{ Stem fresh weight (g) } \\
\hline & Phosphorein & Mycorrhiza & Phosphorein & Mycorrhiza \\
\hline 0 & $22.03 \mathrm{c}$ & $23.56 \mathrm{bc}$ & $25.33 \mathrm{~b}$ & $26.28 \mathrm{ab}$ \\
\hline 30 & $23.00 \mathrm{bc}$ & $27.24 \mathrm{abc}$ & $27.53 \mathrm{ab}$ & $28.20 \mathrm{ab}$ \\
\hline 60 & $28.50 \mathrm{ab}$ & $30.19 \mathrm{a}$ & $29.81 \mathrm{ab}$ & $32.36 \mathrm{a}$ \\
\hline \multirow[t]{3}{*}{90} & $27.41 \mathrm{abc}$ & $28.40 \mathrm{ab}$ & $28.65 \mathrm{ab}$ & $30.27 \mathrm{ab}$ \\
\hline & \multicolumn{4}{|c|}{ Leaves area plant ${ }^{-1}\left(\mathrm{~cm}^{2}\right)$} \\
\hline & Phosphorein & Mycorrhiza & Phosphorein & Mycorrhiza \\
\hline 0 & $683.85 \mathrm{c}$ & $742.17 \mathrm{bc}$ & $785.64 \quad b$ & $829.89 \mathrm{ab}$ \\
\hline 30 & $768.10 \mathrm{abc}$ & $847.36 \mathrm{abc}$ & $863.59 \mathrm{ab}$ & $881.48 \mathrm{ab}$ \\
\hline 60 & $836.51 \mathrm{abc}$ & 910.13 a & $907.30 \mathrm{ab}$ & 977.72 a \\
\hline \multirow[t]{3}{*}{90} & $839.71 \mathrm{abc}$ & $866.82 \mathrm{ab}$ & $878.00 \mathrm{ab}$ & $922.92 \mathrm{ab}$ \\
\hline & \multicolumn{4}{|c|}{ Number of branches plant ${ }^{-1}$} \\
\hline & Phosphorein & Mycorrhiza & Phosphorein & Mycorrhiza \\
\hline 0 & $3.60 \mathrm{c}$ & $3.70 \mathrm{bc}$ & $4.15 \mathrm{~b}$ & $4.20 \mathrm{~b}$ \\
\hline 30 & $4.00 \mathrm{abc}$ & $4.55 \mathrm{a}$ & $4.30 \mathrm{ab}$ & $4.70 \mathrm{ab}$ \\
\hline 60 & $4.25 \mathrm{ab}$ & $4.50 \mathrm{a}$ & $4.70 \mathrm{ab}$ & $4.85 \mathrm{a}$ \\
\hline 90 & $4.20 \mathrm{abc}$ & $4.45 \mathrm{a}$ & $4.55 \mathrm{ab}$ & $4.90 \mathrm{a}$ \\
\hline
\end{tabular}

Values having a common alphabetical letter (s), do not significantly differ, using the revised L.S.D. test at $\mathrm{P}=0.05$

inoculation with the biofertilizer types on vegetative growth characters, varied according to the used phosphours level. The combined treatments, which included the inoculation with phosphorein or Mycorrhiza with 60 or $90 \mathrm{~kg} \mathrm{P}_{2} \mathrm{O}_{5} \mathrm{fed}^{-1}$, were considered the best treatments, as they gave the highest mean values of all studied growth characters, in both seasons. The present results appeared to be in close agreements with those reported by many investigators, e.g. El - Shimi ( 2003 )who found that the application of (100\% of the recommended amount of P) gave the lowest value of leaf area and leaf dry weight, whereas the application of $(75 \% \mathrm{P}+$ Phosphorein ) or $(50 \% \mathrm{P}+$ Phosphorein)gave the highest parameters of leaf area and leaf dry weight of sweet potato plants.

\section{Flowering Traits:}

\section{Effects of the biofertilizer types:}

The presented results in Table (6) indicated that the detected differences between the effects of bean inoculation with Phosphorein or Mycorrhiza on number of flowers plant ${ }^{-1}$ and fruit set percentage appeared insignificant .Similar findings were obtained by Hewedy (1999) on tomato. Srag (2004) found that inoculation of pea seeds with phosphorein significantly increased all yield parameters (No. of pods / plant, average pod weight, yield of green pods / plant, total yield of green pods /fed, number and weight of seeds /pod and weight of 100seds ) compared with the untreated.

\section{Effects of phosphorus fertilizer:}

Regarding the effects of the applied phosphorus fertilizer levels on the flowering traits, the results in Table (6) indicated generally that $\mathrm{P}$ fertilization with 60 and $90 \mathrm{Kg} \mathrm{P}_{2} \mathrm{O}_{5} \mathrm{fed}^{-1}$ increased significantly number of flowers plant ${ }^{-1}$ and fruit set percentage in both seasons, as compared with the unfertilized control. However, the two higher $\mathrm{P}_{2} \mathrm{O}_{5}$ levels (60 and $90 \mathrm{Kg} \mathrm{P}_{2} \mathrm{O}_{5} \mathrm{fed}^{-1}$ ) did not significantly differ in their effects on the three studied parameters. Similar positive findings were obtained by Dawa et al. (2003) on pea who found that increasing $\mathrm{P}$ fertilization up to $200 \mathrm{Kg} \mathrm{P}$ fed $^{-1}$ enhanced plants to flower earlier compared with 100 and $150 \mathrm{Kg} \mathrm{P} \mathrm{fed}^{-1}$. 


\section{Interaction effects:}

The effects of the interaction between biofertilizer types and $\mathrm{P}$ fertilizer levels on number of flowers plant ${ }^{-1}$ and fruit set percentage were found significant in both seasons (Table 7). The combination of Phosphorein or Mycorrhiza and $\mathrm{P}$ at $90 \mathrm{Kg} \mathrm{P}_{2} \mathrm{O}_{5} \mathrm{fed}^{-1}$ increased number of flowers plant ${ }^{-1}$ and fruit set percentage compared to inoculation with phosphorein or AM in both seasons without adding mineral $\mathrm{P}$ fertilizer. These results are in agreement with those obtained by Hamdi (1982) who observed that application of $\mathrm{P}$ without mycorrhizal inoculation increased faba bean yield, but the increase was greater with the inoculation in combination with $\mathrm{P}$ application. The increases in both seasons resulted from biofertilizer inoculation with mineral $\mathrm{P}$ fertilization might be attributed to their combined beneficial effect on improving nutritional status of plants as well as on production of growth regulators i.e. IAA, GA and cytokinins which played together a physiological role in flowering and fruit setting (Arshad and frankenberger, 1991).

\section{Green Pods Yield and its Components:}

Effects of the biofertilizer types:

The effects of biofertilizer types on green pods yield and its components are shown in Table (8). Green pods yield $\mathrm{fed}^{-1}$ reflected significant differences between the two tested biofertilizers in both seasons. Mycorrhizal inoculation plants gave higher yield $\mathrm{fed}^{-1}$ than those inoculated with Phosphorein. It could be concluded that a mycorrhizae inoculation treatments promoted the production of green pods because of the mycorrhizae spores increase the synthesis of the endogenous phytohormons i.e. indole acetic acid (IAA), gibberellic acid (GA3) and cytokinins (CKs) which could play an important role in formation of a big active root system, that allow more nutrient and $\mathrm{P}$ uptake (Arshad and frankenberger, 1991). Poulton et al. (2002) found that mycorrhizal infection and high soil phosphorus improve female and male functions in tomato and increase fruit yield. Also Lau and Stephenson (1994) revealed that the pollen from the high $\mathrm{P}$ soils contained a greater concentration of phosphorus than pollen from the low $\mathrm{P}$

Table (6): The main effects of biofertilizer types and phosphours fertilizer rates on the flowering traits of common bean Plants during the seasons of 2004 and 2005.

\begin{tabular}{|c|c|c|c|c|}
\hline \multirow{2}{*}{ Treatments } & \multicolumn{2}{|c|}{ Number of flowers plant ${ }^{-1}$} & \multicolumn{2}{|c|}{ Fruit set percentage (\%) } \\
\hline & 2004 & 2005 & 2004 & 2005 \\
\hline \multicolumn{5}{|c|}{ Biofertilizer types } \\
\hline Phosphorein & $31.96 \mathrm{a}$ & $36.40 \mathrm{a}$ & $70.88 \mathrm{a}^{*}$ & $68.84 \mathrm{a}$ \\
\hline Mycorrhiza & $32.24 \mathrm{a}$ & $36.38 \mathrm{a}$ & $72.56 \mathrm{a}$ & $72.14 \mathrm{a}$ \\
\hline \multicolumn{5}{|c|}{$P$ rate $\left(\operatorname{kg~P}_{2} \mathrm{O}_{5} \mathrm{fed}^{-1}\right)$} \\
\hline 0 & $21.37 \mathrm{c}$ & $24.30 \mathrm{~b}$ & $61.97 \mathrm{~b}$ & $63.03 \mathrm{~b}$ \\
\hline 30 & $32.92 \mathrm{~b}$ & $41.27 \mathrm{a}$ & $75.35 \mathrm{a}$ & $67.50 \mathrm{~b}$ \\
\hline 60 & $36.35 \mathrm{ab}$ & $40.12 \mathrm{a}$ & $76.30 \mathrm{a}$ & $76.30 \mathrm{a}$ \\
\hline 90 & $37.77 \mathrm{a}$ & $39.87 \mathrm{a}$ & $73.27 \mathrm{a}$ & $75.13 \mathrm{a}$ \\
\hline
\end{tabular}

*Values having a common alphabetical letter (s), do not significantly differ using the revised L.S.D. test at $\mathrm{P}=0.05$.

Table 7. The interaction effects of biofertilizer types and phosphours fertilizer rates on the flowering traits of common bean plants during the fall seasons of 2004 and 2005

\begin{tabular}{|c|c|c|c|c|}
\hline$P$ rate $\left(\mathrm{kg} \mathrm{P}_{2} \mathrm{O}_{5}\right.$ fed $\left.^{-1}\right)$ & \multicolumn{2}{|c|}{2004} & \multicolumn{2}{|c|}{2005} \\
\hline \multicolumn{5}{|c|}{ Number of flowers plant ${ }^{-1}$} \\
\hline & Phosphorein & Mycorrhiza & Phosphorein & Mycorrhiza \\
\hline 0 & $20.45 \mathrm{c}$ & $22.29 \mathrm{c}$ & $23.45 \mathrm{~b}$ & $25.15 \mathrm{~b}$ \\
\hline 30 & $33.95 \mathrm{ab}$ & $31.90 \mathrm{~b}$ & $42.00 \mathrm{a}$ & $40.55 \mathrm{a}$ \\
\hline 60 & $35.40 \mathrm{ab}$ & $37.30 \mathrm{a}$ & $40.25 \mathrm{a}$ & $40.00 \mathrm{a}$ \\
\hline 90 & $38.05 \mathrm{a}$ & $37.50 \mathrm{a}$ & $39.90 \mathrm{a}$ & $39.85 \mathrm{a}$ \\
\hline \multicolumn{5}{|c|}{ Fruit set percentage $(\%)$} \\
\hline & Phosphorein & Mycorrhiza & Phosphorein & Mycorrhiza \\
\hline 0 & $63.28 \mathrm{bc}$ & $60.65 \mathrm{c}$ & $63.30 \mathrm{bc}$ & $62.75 \mathrm{c}$ \\
\hline 30 & $68.73 \mathrm{abc}$ & $81.97 \mathrm{a}$ & $62.77 \mathrm{c}$ & $72.23 \mathrm{ab}$ \\
\hline 60 & $77.54 \mathrm{a}$ & $75.05 \mathrm{ab}$ & $75.41 \mathrm{a}$ & $77.19 \mathrm{a}$ \\
\hline 90 & $73.97 \mathrm{abc}$ & $72.57 \mathrm{abc}$ & $73.87 \mathrm{a}$ & 76.38 a \\
\hline
\end{tabular}

Values having a common alphabetical letter (s), do not significantly differ, using the revised L.S.D. test at P=0.05. 
Table 8.The main effects of biofertilizer types and phosphorus fertilizer rates on green pods yield and its components of common bean plants during the seasons of 2004 and 2005

\begin{tabular}{|c|c|c|c|c|c|c|c|c|}
\hline \multirow[t]{2}{*}{ Treatments } & \multicolumn{2}{|c|}{$\begin{array}{c}\text { Number of green } \\
\text { pods plant }^{-1}\end{array}$} & \multicolumn{2}{|c|}{$\begin{array}{l}\text { Pod length } \\
\text { (cm) }\end{array}$} & \multicolumn{2}{|c|}{$\begin{array}{l}\text { Weight of green pod } \\
(\mathrm{g})\end{array}$} & \multicolumn{2}{|c|}{$\begin{array}{c}\text { Green pods yield fed }^{-1} \\
\text { (ton) }\end{array}$} \\
\hline & 2004 & 2005 & 2004 & 2005 & 2004 & 2005 & 2004 & 2005 \\
\hline \multicolumn{9}{|l|}{ Biofertilizer types } \\
\hline Phosphorein & $22.92 \mathrm{a}^{*}$ & $25.25 \mathrm{a}$ & $9.49 \mathrm{a}$ & $9.83 \mathrm{a}$ & $3.30 \mathrm{a}$ & $3.53 \mathrm{a}$ & $5.07 \mathrm{~b}$ & $6.02 \mathrm{~b}$ \\
\hline $\begin{array}{c}\text { Mycorrhiza } \\
\text { P rate }\left(\mathrm{kg} \mathrm{P}_{2} \mathrm{O}_{5} \mathrm{fed}^{-1}\right.\end{array}$ & $23.62 \mathrm{a}$ & $26.56 \mathrm{a}$ & $9.67 \mathrm{a}$ & 9.94 a & $3.53 \mathrm{a}$ & $3.81 \mathrm{a}$ & $5.78 \mathrm{a}$ & $6.84 \mathrm{a}$ \\
\hline 0 & $13.22 \mathrm{~b}$ & $15.37 \mathrm{~b}$ & $8.76 \mathrm{~b}$ & $8.91 \mathrm{~b}$ & $2.98 \mathrm{~b}$ & $3.32 \mathrm{~b}$ & $2.62 \mathrm{c}$ & $3.36 \mathrm{c}$ \\
\hline 30 & $24.52 \mathrm{a}$ & $27.67 \mathrm{a}$ & $9.46 \mathrm{ab}$ & $9.93 \mathrm{ab}$ & $3.39 \mathrm{a}$ & $3.43 \mathrm{~b}$ & $5.61 \mathrm{~b}$ & $6.35 \mathrm{~b}$ \\
\hline 60 & $27.72 \mathrm{a}$ & $30.62 \mathrm{a}$ & $10.15 \mathrm{a}$ & $10.51 \mathrm{a}$ & $3.68 \mathrm{a}$ & $4.00 \mathrm{a}$ & $6.85 \mathrm{a}$ & $8.18 \mathrm{a}$ \\
\hline 90 & $27.62 \mathrm{a}$ & $29.95 \mathrm{a}$ & $9.96 \mathrm{a}$ & $10.19 \mathrm{a}$ & $3.60 \mathrm{a}$ & $3.94 \mathrm{a}$ & $6.64 \mathrm{a}$ & $7.88 \mathrm{a}$ \\
\hline
\end{tabular}

*Values having a common alphabetical letter (s), do not significantly differ, using the revised L.S.D. test at P=0.05.

soils, perhaps indicating that mycorrhizal infection affects the chemical composition of pollen which, in turn, affects pollen performance and the ability to achieve fertilization. They concluded that Mycorrhiza and $\mathrm{P}$ responses were greater for reproductive traits than vegetative traits.

Similar results were obtained by Hassan et al. (2005) who found that the highest total yield was obtained from plants inoculated with VAM- fungi compared with phosphorein or untreated ones. They reported that the favorable effect of VAM fungi on yield and its components of sweet potato might be due to the symbiotic association between VAM fungi and plant roots where the fungus has the ability to supply the plant with $\mathrm{N}$, certain micronutrients and some hormones. Moreover Attia and Badr El Din (1999) reported that Mycorrhizal inoculation was most effective in increasing maize plant dry weight compared to phosphate dissolving bacteria.

\section{Effect of phosphorus fertilizer:}

Data in Table (8) generally indicated that, increasing $\mathrm{P}$ fertilization level, resulted in successive and significant increments on all yield parameters in both seasons. Concering total yield, the data listed in Table (8), illustrated that increasing $\mathrm{P}$ level from 0 to 60 $\mathrm{kg} \mathrm{P}_{2} \mathrm{O}_{5}$ fed $^{-1}$ resulted in pronounced increments that reached 161.7 and $143.5 \%$ in 2004and 2005 seasons, respectively. Increasing $\mathrm{P}$ application level from 60 to $90 \mathrm{~kg} \mathrm{P}_{2} \mathrm{O}_{5}$ fed $^{-1}$ decreased to some extent mean green pods yield $\mathrm{fed}^{-1}$ of bean plants in both seasons. However, the recorded values were significantly higher than those of the control and $30 \mathrm{~kg} \mathrm{P}_{2} \mathrm{O}_{5}$ fed $^{-1}$ level. Similar results were obtained by Sawires (2001) on chickpea , Abdalla (2002 )on faba bean. Feleaf anf ElAraby (2001) found that the application of $60 \mathrm{~kg} \mathrm{P}_{2} \mathrm{O}_{5}$ $\mathrm{fed}^{-1}$ to the common bean plants led to significant increments on green yield characters , i.e. number and weight of green pods plant ${ }^{-1}$ and total green pods yield fed $^{-1}$.

\section{Interaction Effects:}

Significant effects for the interactions between biofertilizer types and $\mathrm{P}$ fertilization levels on total yield were noticed in both seasons (Table 9). At the three $\mathrm{P}$ application levels of 30,60 and $90 \mathrm{~kg} \mathrm{P}_{2} \mathrm{O}_{5} \mathrm{fed}^{-1}$, micorrhizal inoculated plants produced the higher yield than those of phosphorein inoculated plants. Such favorable interaction effects could be attributed to that he mycorrhizal fungi extended a network of hyphae several centimetres out into the surrounding area, thereby, expanded the total absorption surface of infected plants which improves its access of immobile elements; such as P, Cu, and Zn (Frank, 2002).

\section{Chemical Contents of Leaves:}

\section{Effects of the biofertilizer types:}

Data presented in Table (10) show that the detected differences between influences of seed inoculation with Phosphorein or Mycorrhiza on N, P and K contents in leaves were not significant, in both seasons.

\section{Effect of phosphorus fertilizer:}

The results presented in Table (10) indicated clearly that increasing the applied $\mathrm{P}$ level up to $60 \mathrm{Kg} \mathrm{P}_{2} \mathrm{O}_{5} \mathrm{fed}^{-}$ ${ }^{1}$ consequently and significantly, increased $\mathrm{N}$ and $\mathrm{P}$ contents of leaves over that of the control treatment, in the two seasons. Raising the applied $\mathrm{P}$ level to 90 $\mathrm{P}_{2} \mathrm{O}_{5} \mathrm{fed}^{-1}$ was not associated with sufficient increments on the aforementioned chemical contents of leaves. On the other hand the four applied $\mathrm{P}$ levels did not significantly differ in their effects on the leaves in the two growing seasons.

The simulative effect of $\mathrm{P}$ supply on $\mathrm{N}$ and $\mathrm{P}$ contents of leaves might be attributed to the increased amount of available phosphorous and / or the increased in absorbing efficiency of plant roots. Similar trend were reported by Mahmoud and El-Hefny (1999) on onion; Dawa et al.(2003) and Srag (2004) on pea and illustrated that phosphorus contents in pea shoots increased with increasing the level of applied phosphorus fertilizer. 
Table 9. The interaction effects of biofertilizer types and phosphours fertilizer rates on green pods yield and its components of common bean plants during the seasons of 2004 and 2005

\begin{tabular}{|c|c|c|c|c|}
\hline \multirow{3}{*}{$P$ rate $\left(\mathrm{kg} \mathrm{P}_{2} \mathrm{O}_{5}\right.$ fed $\left.^{-1}\right)$} & \multicolumn{2}{|c|}{2004} & \multicolumn{2}{|c|}{2005} \\
\hline & Phosnhroin & Number of gree & ods plant ${ }^{-1}$ & Mycorrhiza \\
\hline & I IIOSpHotem & & 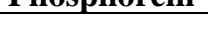 & Angeconima \\
\hline \multirow{6}{*}{$\begin{array}{c}0 \\
30 \\
60 \\
90\end{array}$} & $12.95 \mathrm{~b}^{*}$ & $13.50 \mathrm{~b}$ & $14.95 \mathrm{c}$ & $15.80 \mathrm{c}$ \\
\hline & $23.20 \mathrm{a}$ & $25.85 \mathrm{a}$ & $26.25 \mathrm{~b}$ & $29.10 \mathrm{ab}$ \\
\hline & $27.40 \mathrm{a}$ & $28.05 \mathrm{a}$ & $30.30 \mathrm{ab}$ & $30.95 \mathrm{a}$ \\
\hline & $28.15 \mathrm{a}$ & $27.10 \mathrm{a}$ & $29.50 \mathrm{ab}$ & $30.40 \mathrm{a}$ \\
\hline & \multicolumn{4}{|c|}{ Length of green pod $(\mathrm{cm})$} \\
\hline & Phosphorein & Mycorrhiza & Phosphorein & Mycorrhiza \\
\hline \multirow{6}{*}{$\begin{array}{c}0 \\
30 \\
60 \\
90\end{array}$} & $9.87 \mathrm{bc}$ & $9.65 \mathrm{c}$ & $10.00 \mathrm{~b}$ & $9.82 \mathrm{~b}$ \\
\hline & $10.57 \mathrm{abc}$ & $10.35 \mathrm{abc}$ & $11.02 \mathrm{ab}$ & $10.85 \mathrm{ab}$ \\
\hline & $11.25 \mathrm{a}$ & $11.05 \mathrm{a}$ & $11.55 \mathrm{a}$ & $11.47 \mathrm{a}$ \\
\hline & $11.00 \mathrm{ab}$ & $10.92 a b$ & $11.20 \mathrm{ab}$ & $11.17 \mathrm{ab}$ \\
\hline & \multicolumn{4}{|c|}{ Weight of green pod (g) } \\
\hline & Phosphorein & Mycorrhiza & Phosphorein & Mycorrhiza \\
\hline 0 & $2.76 \mathrm{c}$ & $3.20 \mathrm{bc}$ & $3.41 \mathrm{~b}$ & $3.22 \mathrm{~b}$ \\
\hline 30 & $3.42 \mathrm{~b}$ & $3.37 \mathrm{~b}$ & $3.39 \mathrm{~b}$ & $3.47 \mathrm{~b}$ \\
\hline 60 & $3.98 \mathrm{a}$ & $3.38 \mathrm{~b}$ & $4.27 \mathrm{a}$ & $3.74 \mathrm{ab}$ \\
\hline \multirow[t]{2}{*}{90} & $3.97 \mathrm{a}$ & $3.24 \mathrm{bc}$ & $4.17 \mathrm{a}$ & $3.71 \mathrm{ab}$ \\
\hline & \multicolumn{4}{|c|}{ 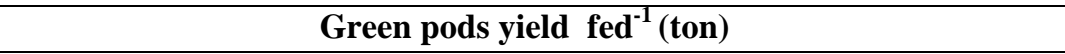 } \\
\hline & Phosphorein & Mycorrhiza & Phosphorein & Mycorrhiza \\
\hline 0 & $2.78 \mathrm{~d}$ & $3.07 \mathrm{~d}$ & $3.19 \mathrm{f}$ & $3.189 \mathrm{f}$ \\
\hline 30 & $5.37 \mathrm{c}$ & $5.84 \mathrm{c}$ & $5.897 \mathrm{e}$ & $6.55 \mathrm{de}$ \\
\hline $\begin{array}{l}60 \\
90\end{array}$ & $6.83 \mathrm{bc}$ & 7.98 a & $7.55 \mathrm{bc}$ & $6.63 \mathrm{~b}$ \\
\hline & $6.96 \mathrm{bc}$ & $7.53 \mathrm{ab}$ & $6.37 \mathrm{~cd}$ & $8.05 \mathrm{a}$ \\
\hline
\end{tabular}

*Values having a common alphabetical letter (s), do not significantly differ, using the revised L.S.D. test at P=0.05.

Table 10. The main effects of biofertilizer types and phosphorus fertilizer rates on the chemical constituent of leaves of common bean plants during the fall seasons of 2004 and 2005

\begin{tabular}{|c|c|c|c|c|c|c|}
\hline \multirow{2}{*}{ Treatments } & \multicolumn{2}{|c|}{$\mathbf{N}(\%)$} & \multicolumn{2}{|c|}{$\mathbf{P}(\%)$} & \multicolumn{2}{|c|}{$\mathrm{K}(\%)$} \\
\hline & 2004 & 2005 & 2004 & 2005 & 2004 & 2005 \\
\hline Biofertilizer types & & & & & & \\
\hline Phosphorein & $3.30 \mathrm{a}^{*}$ & $3.42 \mathrm{a}$ & $0.34 \mathrm{a}$ & $0.36 \mathrm{a}$ & $2.16 \mathrm{a}$ & $2.18 \mathrm{a}$ \\
\hline $\begin{array}{c}\text { Mycorrhiza } \\
\text { P rate }\left(\mathbf{k g ~ P}_{\mathbf{2}} \mathbf{O}_{5} \text { fed }^{-1}\right)\end{array}$ & $3.54 \mathrm{a}$ & $3.71 \mathrm{a}$ & $0.38 \mathrm{a}$ & $0.40 \mathrm{a}$ & $2.16 \mathrm{a}$ & $2.20 \mathrm{a}$ \\
\hline 0 & $3.02 \mathrm{c}$ & $3.05 \mathrm{c}$ & $0.21 \mathrm{c}$ & $0.25 \mathrm{c}$ & $2.08 \mathrm{a}$ & $2.09 \mathrm{a}$ \\
\hline 30 & $3.23 \mathrm{bc}$ & $3.35 \mathrm{bc}$ & $0.32 \mathrm{~b}$ & $0.35 \mathrm{~b}$ & $2.17 \mathrm{a}$ & $2.21 \mathrm{a}$ \\
\hline 60 & $3.81 \mathrm{a}$ & 3.99 a & $0.48 \mathrm{a}$ & $0.50 \mathrm{a}$ & $2.23 \mathrm{a}$ & $2.25 \mathrm{a}$ \\
\hline 90 & $3.62 \mathrm{ab}$ & $3.87 \mathrm{ab}$ & $0.43 \mathrm{a}$ & $0.46 \mathrm{a}$ & $2.17 \mathrm{a}$ & $2.22 \mathrm{a}$ \\
\hline
\end{tabular}

*Values having a common alphabetical letter (s), do not significantly differ, using the revised L.S.D. test at P=0.05.

Also Abdalla (2002) found that N, P and K contents of faba bean leaves increased due to increasing $\mathrm{P}$ level from 100 to $200 \mathrm{~kg}$ super phosphate $\mathrm{fed}^{-1}$.

Interaction Effects:

The results of the interaction effects of biofertilizer types and $\mathrm{P}$ fertilizer rates (Table11) reflected significant effects on the percentages of $\mathrm{N}$ and $\mathrm{P}$ and in leaves in both seasons. However, $\mathrm{K}$ content in leaves did not show any significantly effects.
It is evident from Table (11) that the plants which received $\mathrm{P}$ at 60 or $90 \mathrm{~kg} \mathrm{P}_{2} \mathrm{O}_{5} \mathrm{fed}^{-1}$ and inoculated with Mycorrhiza or Phosphorein produced higher mean values than those of the control in both seasons. It was also clear that the fertilized plants with $60 \mathrm{~kg} \mathrm{P}_{2} \mathrm{O}_{5} \mathrm{fed}^{-1}$ in the presence of Mycorrhiza almost gave the highest values of $\mathrm{N}$ and $\mathrm{P}$ contents in leaves in both seasons. These results are in agreement with those reported by Abdalla (1998) on onion. Gendiah (1999) found that Mycorrhiza fungus increased $\mathrm{N}$ and $\mathrm{P}$ contents in tomato leaves as well as $\mathrm{P}$ content in roots. 
Table 11. The interaction effects of biofertilizer types and phosphours fertilizer rates on the chemical constituent of leaves of common bean plants during the fall seasons of 2004 and 2005

\begin{tabular}{|c|c|c|c|c|}
\hline \multirow[t]{3}{*}{$P$ rate $\left(\mathrm{kg} \mathrm{P}_{2} \mathrm{O}_{5}\right.$ fed $\left.^{-1}\right)$} & \multicolumn{2}{|c|}{2004} & \multicolumn{2}{|c|}{2005} \\
\hline & \multicolumn{3}{|c|}{ N\% } & \\
\hline & Phosphorein & Mycorrhiza & Phosphorein & Mycorrhiza \\
\hline 0 & $3.00 \mathrm{c}^{*}$ & $3.05 \mathrm{bc}$ & $3.02 \mathrm{c}$ & $3.09 \mathrm{c}$ \\
\hline 30 & $3.21 \mathrm{bc}$ & $3.26 \mathrm{bc}$ & $3.30 \mathrm{c}$ & $3.39 \mathrm{bc}$ \\
\hline 60 & $3.56 \mathrm{abc}$ & $4.07 \mathrm{a}$ & $3.76 \mathrm{abc}$ & $4.23 \mathrm{a}$ \\
\hline \multirow[t]{3}{*}{90} & $3.44 \mathrm{abc}$ & $3.80 \mathrm{ab}$ & $3.61 \mathrm{abc}$ & $4.13 \mathrm{ab}$ \\
\hline & \multicolumn{3}{|c|}{$\mathbf{P \%}$} & \\
\hline & Phosphorein & Mycorrhiza & Phosphorein & Mycorrhiza \\
\hline 0 & $0.20 \mathrm{e}$ & $0.23 \mathrm{de}$ & $0.21 \mathrm{~d}$ & $0.24 \mathrm{~d}$ \\
\hline 30 & $0.31 \mathrm{~d}$ & $0.34 \mathrm{~cd}$ & $0.34 \mathrm{c}$ & $0.35 \mathrm{c}$ \\
\hline 60 & $0.46 \mathrm{ab}$ & $0.50 \mathrm{a}$ & $0.48 \mathrm{ab}$ & $0.53 \mathrm{a}$ \\
\hline \multirow[t]{3}{*}{90} & $0.40 \mathrm{bc}$ & $0.47 \mathrm{ab}$ & $0.43 \mathrm{~b}$ & $0.49 a b$ \\
\hline & \multicolumn{3}{|c|}{ K\% } & \\
\hline & Phosphorein & Mycorrhiza & Phosphorein & Mycorrhiza \\
\hline 0 & 2.09 & 2.07 & 2.07 & 2.10 \\
\hline 30 & 2.16 & 2.18 & 2.19 & 2.23 \\
\hline 60 & 2.22 & 2.23 & 2.24 & 2.25 \\
\hline 90 & 2.17 & 2.17 & 2.21 & 2.22 \\
\hline
\end{tabular}

*Values having a common alphabetical letter (s), do not significantly differ, using the revised L.S.D. test at P=0.05.

\section{REFERENCES}

Abdalla, A.G. (1998). Onion yield as influenced by inoculation with Mycorrhizal fungi, organic Matter and Nitrogen fertilizer in sandy soil J. Agric; Res. Menofiya Univ., 23(1): 77-88.

Abdalla, A.M. (2002). Effect of bio - and mineral phosphorus Fertilizer on the growth, productivity and nutritional value of faba bean. Egypt. J. Hort., 29(2): 187-203.

Agricultural statistics. (2004). Economic Affairs' sector, central administration for agricultural economic, ministry of agriculture and land reclamation, Egypt. Vol. 1 (winter crops).

Allen, M.F. and M.G. Boosalis. (1983). Effects of two species of VA mycorrhizal fungi on drought tolerance of winter wheat. New phytol., 93: 67-76.

Al-Rawy, K.M. and A.M. Khalf-Allah. (1980). Design and Analysis of Agricultural Experiments. Text book. ElMousil Univ. press Ninawa, Iraq. pp.487.

Arshad, M. and W.T. Frankenberger. (1991). Microbiological production of plant hormones. In: Keister, D.L.; Cregan, P.B. (Ed.). The rhizosphere and plant growth. Dordrecht: Kluwer. p. 327-334.

Ashour, S.M. (1998). Influece of biofertilizers and phosphorus application on growth and yield of potato. J. Agri. Sci. Mansoura Univ., 23 (7): 3351-3358.

Attia,M. and S.M. Badr El-Din (1999). The interaction between arbuscular mycorrhizal fungi and Bacillus megaterium on effects on growth and nutrient uptake of maize plants grown in a clay loam soil. Egypt J. Microbiol. 34: 479- 487.

Bennink, M.R. (2001). Global Importance of Common Bean. http://www.michiganbean.org/beanBag/beanBag.html.

Chapman, H. D and P. f. Pratt. (1978). Methods of Analysis for Soils, Plants and Waters. Division of Agriculture Sciences, University of California, Davis, pp 50.

Dawa, K.E., A.A Tartoura and M.A. Darweesh. (2003). Effect of phosphorus fertilization and some growth promoters on growth and yield pea (Pisum sativum L) J. Agric. Sci. Mansoura Univ., 28 (2): 1327-1343.

Dorneless, M. R., C. M Da Silva, and A. A. Gomes, 2001. A model for hyphae effects in phosphorus absorption by plants. Ecological Modeling, 142: 83-89

El-Kalla, S.E., A.K. Mostafa, A.A. Ellah , and A.A. Awad (1997). Mineral and bio-phosphatic fertilization for intercropped faba bean and onion. 1 . Agron. Dept., Fac. of Agric. Mansoura Univ., Egypt. 2- Onion Research setion, Field crop Res. Inst., Agric. Research center, Egypt.

El-Shamma, H.A. (2000). Effect of chemical and biofertilizers on growth, seed and Quality of new cultivar of dry bean. Annals of Agric. Sci. Moshtohor., 38 (1): 461 - 478.

El-Shimi, A.A. (2003). Effect of some levels of phosphorus fertilization and Phosphorein biofertilizer on growth, yield and chemical composition of some sweet potato cultivars. J. Agric. Sci. Mansoura Univ., 28 (4): 2889-2901.

FAO. 2003. Food and Agriculture Organization of the United Nations . FAOSTAT Agriculture Data .http://www.fao.org.Statistics . 
Fayed , A .M . (1997). Evolution of some cultivars and mutants of cow pea (Vigna unguiculata L. Walp ) under Kafr EL Sheikh condition. M.Sc. Thesis, Faculty of Agric, Kafr EL-Sheikh, Tanta University .

Feleafel, M.N. and S. M. El-Araby. (2001). Response of snap bean cultivars (phaseolus vulgaris L.) to varying rates of nitrogen and phosphorus fertilization. J. Agric. Sci. Mansoura Univ., 26 (3): 1735-1748.

Frank, W. Smith (2002). The phosphate uptake mechanism. Plant and Soil, 245: 105-114.

Gendiah, H.M. (1999). Effect of biofertilization by using Mycorrhizal fungus and Rhizobium sp. bacteria on the growth and macro nutrients of Manzanillo olive seedlings Annals of Agric. Sci. Moshtohor, 37 (1): 575-584.

Hamdi, YA. 1982. Symbiotic nitrogen fixation in faba bean. In: Hawtin, G. and C. Webb (eds.), Faba bean Improvement, pp: 127-38.

Hamel, C., Y. Dalpe, V. Furlan, and S. Parent. (1997). Indigenous populations of arbuscular mycorrhizal fungi and soil aggregate stability are major determinants of leek (Allium porrum L.) response to inoculation with Glomus intraradices or Glomus versiforme. Mycorrhiza, 7: 187196.

Hassan, M.A., S.K El-Seifi, F.A. Omara, and U.M. Saif ElDeen. (2005). Effect of mineral and bio- phosphate fertilization and foliar application of micro nutrients on growth, yield and quality of sweet potato (Ipomoea batatas L) 1- vegetative growth, yield and tuber root characteristics 2- chemical composition of leaves and cured tuber roots. J. Agric. Sci. Mansoura Univ., 30 (10): 6149-6182.

Hewady, A.M. (1999). Effect of sulphur application and biofertilizer phosphorein on growth and productivity of tomato. Minufiya J. of Agric. Res., 24 (3): 1063-1078.

Jackson, M. L., (1967). Soil chemical analysis. Verlag. Prentia. Hall inc., Englewood. Cliffs, USA.

Lau, T C., and A. G. Stephenson. 1994. Effects of soil phosphorus on pollen production, pollen size, pollen phosphorus content, and the ability to sire seeds in Cucurbita pepo (Cucurbitaceae). Sexual Plant Reproduction 7:215-220.
Ling, E.R. (1963). Determination of total nitrogen by semimicro Kjeldahl method. Dairy Chem., 11: 23-84.

Mahmoud, H.A. and E. M. El-Hefny. (1999). Effect of Mycorrhizal infection and phosphorus concentrations on onion plant. Annals of Agric. Sci. Moshthor, 37 (3): 1805-1817.

Marschner, H. (1995) Mineral nutrition of higher plants $2^{\text {nd }}$ Edition, Academic Press, London, UK.

Pachico, D. 1993. The demand for bean technology, pp. 6073. In G. Henry (ed.), Trends in CIAT commodities. Centro International de4 Agricultura Tropical (CIAT). Cali, Colombia.

Page., A.L., R.H. Miller, and D.R .Keeney. (1982). Methods of soil analysis, chemical and microbiological properties, part 2, $2^{\text {nd }}$ ed. ASA-SSSA, Madison, Wisc., USA.

Roncadori, R.W. and R.S. Hussey. (1977). Interaction on the endomycorrhizal fungus Gigaspora margarita and rootknot nematode on cotton. Phytopathology, 67: 15071511 .

Poulton, J. L., Bryla, D. R., Koide, R. T. \& Stephenson, A. G. (2002). Mycorrhizal infection and high soil phosphorus improve vegetative growth and the female and male functions in tomato. New Phytologist, 154: 255-264.

Ruiz-lozano, J., R. Azcon, and M. Gomez, (1996). Alleviation of salt stress by arbuscular mycorrhizal Glomus species in Lactuca sativa plants. Physiol. Plant., 98: 767-772.

Russell. E.W. (1973). Soil condition and plant growth. Longman, London. $10^{\text {th }}$ Ed. pp. 37.

Srag, S.M.A. (2004) Influence of seed inoculation with phosphorein and levels of phosphorus fertilization on growth, mineral contents, seedless green pods yield and yield of seeds of three sugar pea cultivars under sandy soil conditions. J. Agric. Sci. Mansoura Univ., 29 (8): 4729- 4744.

SAS. (1996). Software program. Cary, North Carolina State. Univ., Karl M Glsener. USA.

Sawires, E. (2001). Effect of phosphorus fertilization and micro nutrients on yield and yield components of chick pea (cicera rietinuml) Annals Agric -Sci., Ain Shams Univ. Cairo, 46 (1): 155-164.

Schmirer, J. and T. Rosswall, 1987. Mineralization of nitrogen from $\mathrm{N}^{15}$ labelled fungi, soil microbial biomass and root and its up-take by barley plants. Pl. Soil, 102: 71-79. 


\section{الملخص العربي}

\section{دراسة مقارنة بين تأثيركل من فطر الميكوريزا والبكتيريا المذيبة للفوسفات على صفات النمو والخصول}

\section{والختوى الكيميائى عند مستويات مختلفة من التسميد الفوسفورى المعلدن في الفاصوليا}

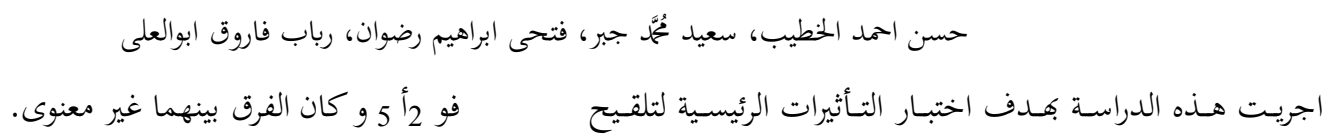

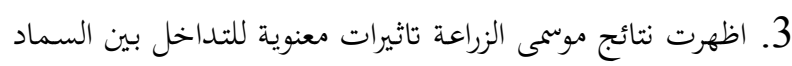

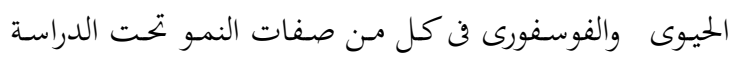

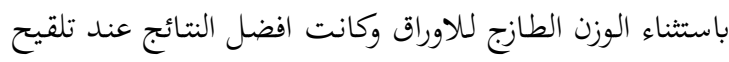

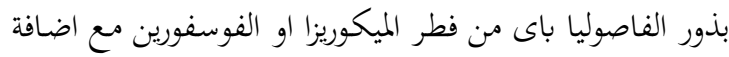

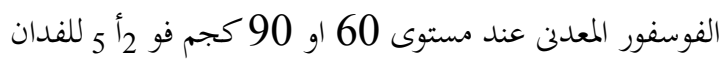

الازهار

1. اوضحت الدراسة انه لاتوجد فروق معنوية بين تأثير كلا من

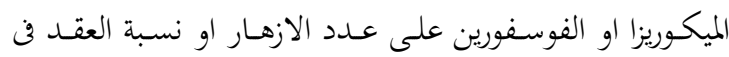
الثمار فن موسمى الزراعة .

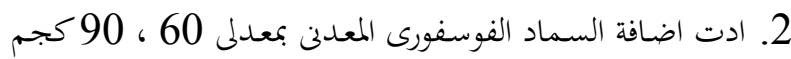

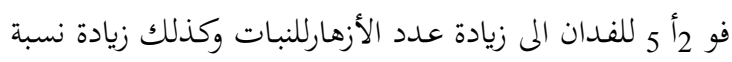
عقد الثمار مقارنة بالكنترول في كل من موسمي الزراعة .

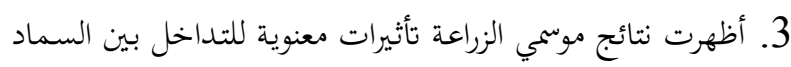
الحيوى والفوسفورى المعدنى على عدد الازهار ونسبة عقد الثمار وكانت افضل معاملة عاملية هى تلقيح بذور الفاصوليا بكل من

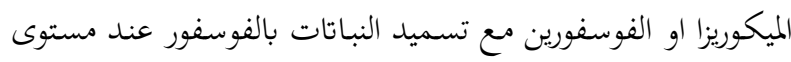
60 او 90 كجم فو 2أ 5 للفدان. محصول القرون الخضراء ومكوناته:

أوضحت الدراسة أن تلقيح بذور الفاصوليا بالميكوريزا أدى إلى إلى

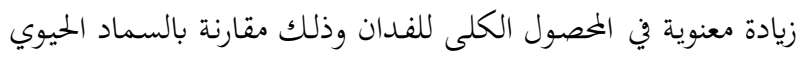
فوسفورين بينما لم تختلف باقي الصفات معنويا مثل عدد القرون الخضراء للنبات وطول ووزن القرن.

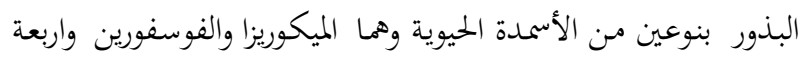

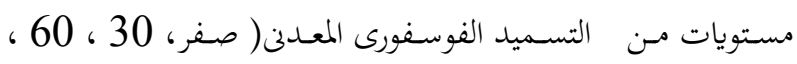

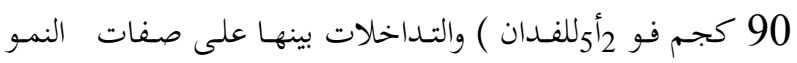

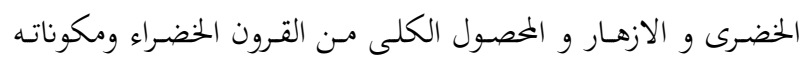

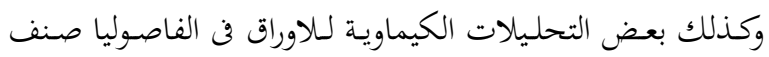
برونكو. اجريت بتربتان حقليتان خلال موسمى2004و 2005 في مزرعة كلية الزراعة بدمنهوربنطقة البستان بمحافظة البحيرة , جمهورية مصر العربية. تم تنغيذ التجارب باستخدام القطاعات العشوائية الكاملة بأربع مكررات. يمكن تلخيص النتائج المتحصل عليها على النحو التالى: صفات النمو الحضرى:

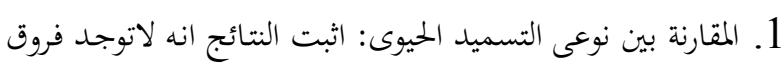

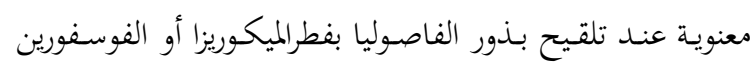

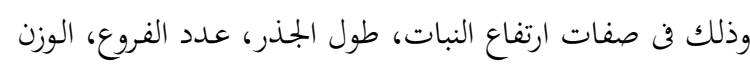

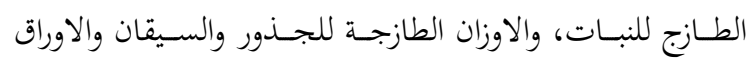
وكذلك المساحة الورقية في كل من موسمى الزراعة.

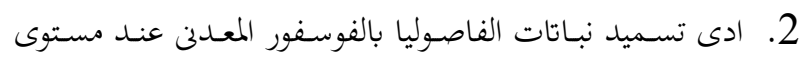

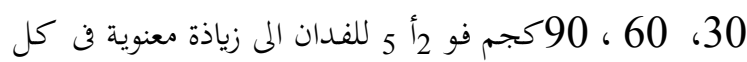

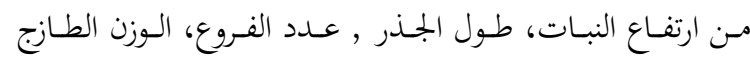

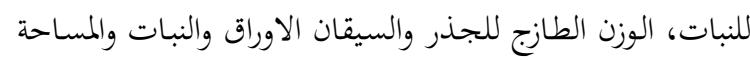

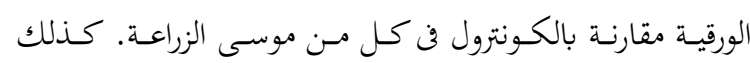

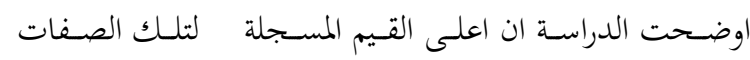

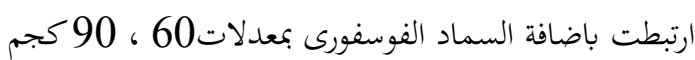


2. أدت إضافة السماد الفوسفورى بالمعدلات 60 ، 90 كجمى فو

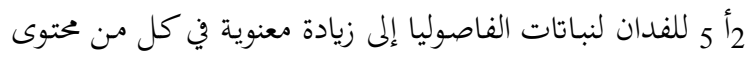

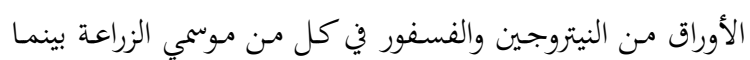

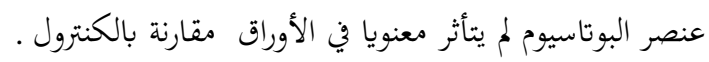

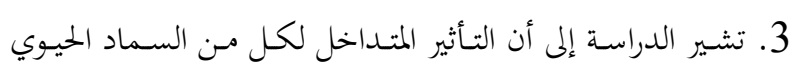

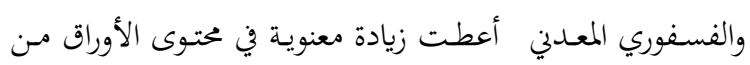
عناصـر النيتروجـين والفسفور وتوضـح الدراسـة أيضـا إن عنصـر

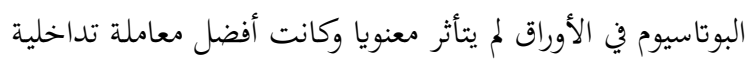

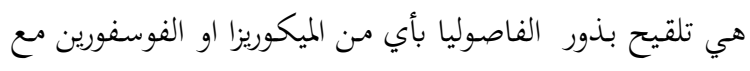

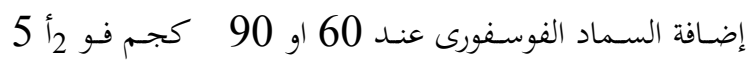
للفدان . وتوصى الدراسة بصفه عامة أن تلقيح بذور الفاصوليا بالميكوريزا

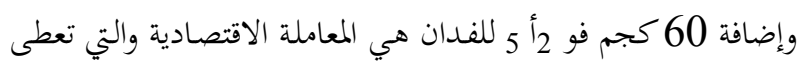
أعلى محصول مع جودة عالية وذلك تحت الظروف البيئة السائدة في محافظة البحيرة والمناطق المشابهة لها، كما تفيد الدراسة بان استخدام الأسمدة الحيوية يؤدى إلى تخفيض السماد الفوسفورى المعدني.
معنوية في المحصول الكلى للقرون الخضراء والمحصول الأخضر للنبات وعدد وطول ووزن القرون الخضراء وذلك مقارنة بمعاملة الكنترول في

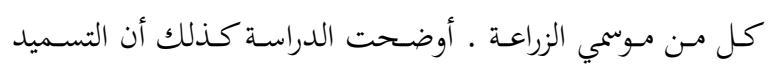

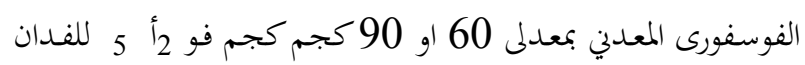
أعطى أفضل النتائج و كان الفرق بينهما غير معنوي . أظهرت نتائج موسمي الزراعة تأثيرات معنوية للتداخل بين السماد

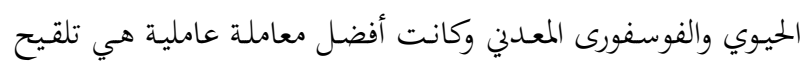

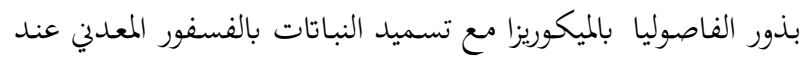
مستوى 60 كجم كجم فو 2أ 5 للفدان حيث أعطت أفضل النتائج

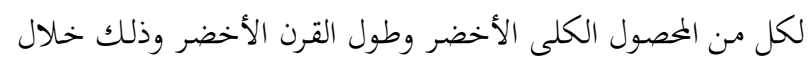

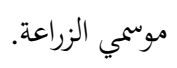
المحتوى الكيماوي للأوراق: 1. أوضحت الدراسة أنه لاتوجد فروق معنوية بين تاثير الميكوريزا او

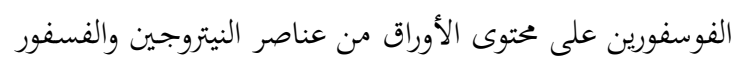

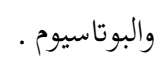

أظهرت الدراسة أن إضافة الفسفور المعدني بمعدلات 30 ،606 ، 30 ،

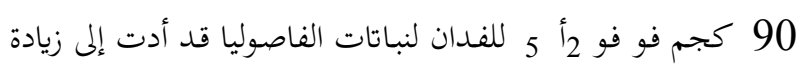

